\title{
ESTROGEN-CONCENTRATING NEUROPHYSIN-CONTAINING HYPOTHALAMIC MAGNOCELLULAR NEURONS IN THE VASOPRESSIN-DEFICIENT (BRATTLEBORO) RAT: A STUDY COMBINING STEROID AUTORADIOGRAPHY AND IMMUNOCYTOCHEMISTRY ${ }^{1}$
}

\author{
C. H. RHODES, ${ }^{2}$ J. I. MORRELL, ${ }^{3}$ AND D. W. PFAFF \\ Rockefeller University, New York, New York 10021
}

Received November 23, 1981; Revised May 13, 1982; Accepted June 18, 1982

\begin{abstract}
This report describes the distribution of neurophysin-containing, estradiol-concentrating neurons in a strain of rat which is congenitally unable to produce vasopressin and its associated neurophysin (the Brattleboro rat). In this strain of rat, all of the neurophysin-containing cells are oxytocin producing. The magnocellular neurons which produce vasopressin in the normal rat are present in their normal numbers and normal locations (Rhodes, C. H., J. I. Morrell, and D. W. Pfaff (1981) J. Comp. Neurol. 198: 45-64) and can be identified as the neurophysin-negative magnocellular neurons.

Estradiol-concentrating cell nuclei were observed in magnocellular neurons with neurophysincontaining cytoplasm as well as in magnocellular neurons lacking immunocytochemically detectable neurophysin. The majority of these neurons were found in the paraventricular nucleus (PVN), ventral and medial to its lateral subnucleus, and in the posterior subnucleus of the PVN. There were, in addition, many neurophysin-containing and neurophysin-lacking magnocellular neurons with nuclei which did not concentrate estradiol. Within the PVN, the majority of the neurophysinnegative, non-estradiol-concentrating neurons were in the lateral subnucleus, while the majority of the neurophysin-positive, non-estradiol-concentrating neurons were in the medial subnucleus.

Comparison of the results of experiments using homozygous Brattleboro rats with the results of similar experiments using the (normal) parent strain Long-Evans rat suggests that, in the normal animals, there are both oxytocin- and vasopressin-producing neurons which concentrate estradiol. Comparison of these observations with published descriptions of the anatomical distribution of neurons which project to the medulla or spinal cord suggests that many of the oxytocin- or vasopressin-containing, estrogen-concentrating neurons in the PVN send axons to regions regulating autonomic functions.
\end{abstract}

Estrogen treatment is a stimulus for the release of oxytocin (Yamaguchi et al., 1979) and vasopressin (Skowsky et al., 1979). A decrease in immunocytochem-

\footnotetext{
${ }^{1}$ This paper is dedicated to the Rev. Dr. Winthrop Brainerd, Rector of Christ's Church, Baltimore, formerly Keeper of Books and Manuscripts of Her Majesty's College of Heralds, and author of Codici Monastici Ethiopiani.

We wish to thank E. A. Zimmerman for the anti-neurophysin antiserum used in this work. This work was supported in part by National Institutes of Health Grants HD 05751 and HD 16327. C. H. R. was the recipient of National Research Service Award 5T32GM07739.

${ }^{2}$ Present address: Department of Pathology, Hospital of the University of Pennsylvania, Philadelphia, PA 19104.

${ }^{3}$ To whom correspondence should be addressed at Rockefeller University, 1230 York Avenue, New York, NY 10021.
}

ically identified oxytocin has been observed in the anterior commissural nucleus (ACN) in response to estrogen treatment (Rhodes et al., 1981c). It is not known whether other magnocellular cell groups also participate in the estrogen-stimulated increase in plasma oxytocin levels or where estrogen acts to produce this effect. The fall in pituitary oxytocin content during proestrus and estrus in normal cycling female rats observed by Crowley et al. (1978) suggests that physiological changes in ovarian steroid levels affect the release of posterior pituitary peptides.

The combination of steroid autoradiography and immunocytochemistry has been used to identify neurophysin-containing, estradiol-concentrating neurons in the (normal) parent strain Long-Evans rat (Rhodes et al., 1981a). That work was done with a primary antiserum 
which cross-reacts with both of the rat neurophysins and therefore was unable to distinguish between oxytocinand vasopressin-producing cells. Similar experiments in this laboratory with anti-vasopressin and anti-oxytocin primary antisera gave technically unsatisfactory immunocytochemical results. The anti-neurophysin antiserum used in the previous work therefore was used to study the distribution of estrogen-concentrating, neurophysincontaining cells in the Brattleboro rat in which it specifically stained the oxytocin-containing cells since only the oxytocin-associated neurophysin is produced by that animal (Burford et al., 1971).

\section{Materials and Methods}

To reduce endogenous estrogen levels, six homozygous Brattleboro adult female rats (Blue Spruce Farms, Altamont, NY) were ovariectomized 1 month before isotope injection. Four of the animals received $0.3 \mu \mathrm{g}$ of $[2,4,6,7-$ $\left.{ }^{3} \mathrm{H}\right]$ estradiol/100 gm of body weight (New England Nuclear; specific activity, $90 \mathrm{Ci} / \mathrm{mmol}$ ) in $0.2 \mathrm{ml}$ of ethanol mixed with an equal volume of physiological saline and given in two equal doses injected intraperitoneally $0.5 \mathrm{hr}$ apart. Two of the animals (numbers 14 and 15) received twice this dose. Two $\mathrm{hr}$ after the final injection, the animals were sacrificed by decapitation. Blocks, $1-\mathrm{cm}^{3}$, containing ACN, PVN (paraventricular nucleus), and SON (supraoptic nucleus) were frozen and stored in liquid nitrogen.

Six-micrometer transverse sections were cut on a Harris International Equipment Co. cryostat at $-20^{\circ} \mathrm{C}$ and mounted on slides coated with Kodak NTB-3 nuclear emulsion. The section sampling frequency varied between every section and one section in four through the region of interest. The autoradiograms were exposed at $4^{\circ} \mathrm{C}$ for up to 18 months in a lead-lined box containing desiccant. After exposure, the slides were fixed with $3 \%$ paraformaldehyde for $30 \mathrm{sec}$ at $4^{\circ} \mathrm{C}$ (modified after Keefer et al., 1976). Then, the autoradiograms were developed in Kodak D19 at $16^{\circ} \mathrm{C}$ for $2 \mathrm{~min}$, rinsed in Kodak liquid Hardener Stop Bath for $1 \mathrm{~min}\left(21^{\circ} \mathrm{C}\right)$, and fixed with Kodak Fixer for $18 \min \left(21^{\circ} \mathrm{C}\right)$. The combination steroid autoradiographic and immunocytochemical technique has been described (Rhodes et al., 1981a). Details of the autoradiographic technique have been reported (Pfaff and Keiner, 1973; Morrell and Pfaff, 1981).

The immunohistologic technique was basically that of Sternberger (1974). A rabbit anti-bovine neurophysin I (provided by E. A. Zimmerman) which cross-reacts with both of the rat neurophysins was used as the primary antiserum. Immediately after the photographic procedures, the autoradiograms were rinsed in water and then in phosphate-buffered saline, $\mathrm{pH} 7.2$ (PBS). They then were covered with a drop of the primary antiserum diluted 1:1000 with PBS and left in a moist chamber at $4^{\circ} \mathrm{C}$ for about $48 \mathrm{hr}$. The rest of the procedure, except for the reaction with diaminobenzidine (DAB), was done at room temperature. The tissue was washed in three changes of PBS, covered with a drop of the goat antirabbit antiserum diluted 1:100 (Cappel Laboratories) for $30 \mathrm{~min}$, washed in two changes of PBS, and covered with a drop of the peroxidase-antiperoxidase complex diluted 1:200 (Sternberger-Meyer Laboratories) for $60 \mathrm{~min}$. The sections then were washed in two changes of PBS and one of $0.05 \mathrm{M}$ Tris buffer $(\mathrm{pH} 7.6)$ and incubated in a solution of $50 \mu \mathrm{g} / \mathrm{ml}$ of DAB (G. F. Smith Chemical Co., lot R2) in $0.05 \mathrm{M}$ Tris buffer ( $\mathrm{pH} 7.6$ ) with $1.5 \mathrm{ml} /$ liter of $3 \% \mathrm{H}_{2} \mathrm{O}_{2}$ for $10 \mathrm{~min}$ at $21^{\circ} \mathrm{C}$. An additional $1.5 \mathrm{ml} /$ liter of $3 \% \mathrm{H}_{2} \mathrm{O}_{2}$ was added and the incubation continued for an
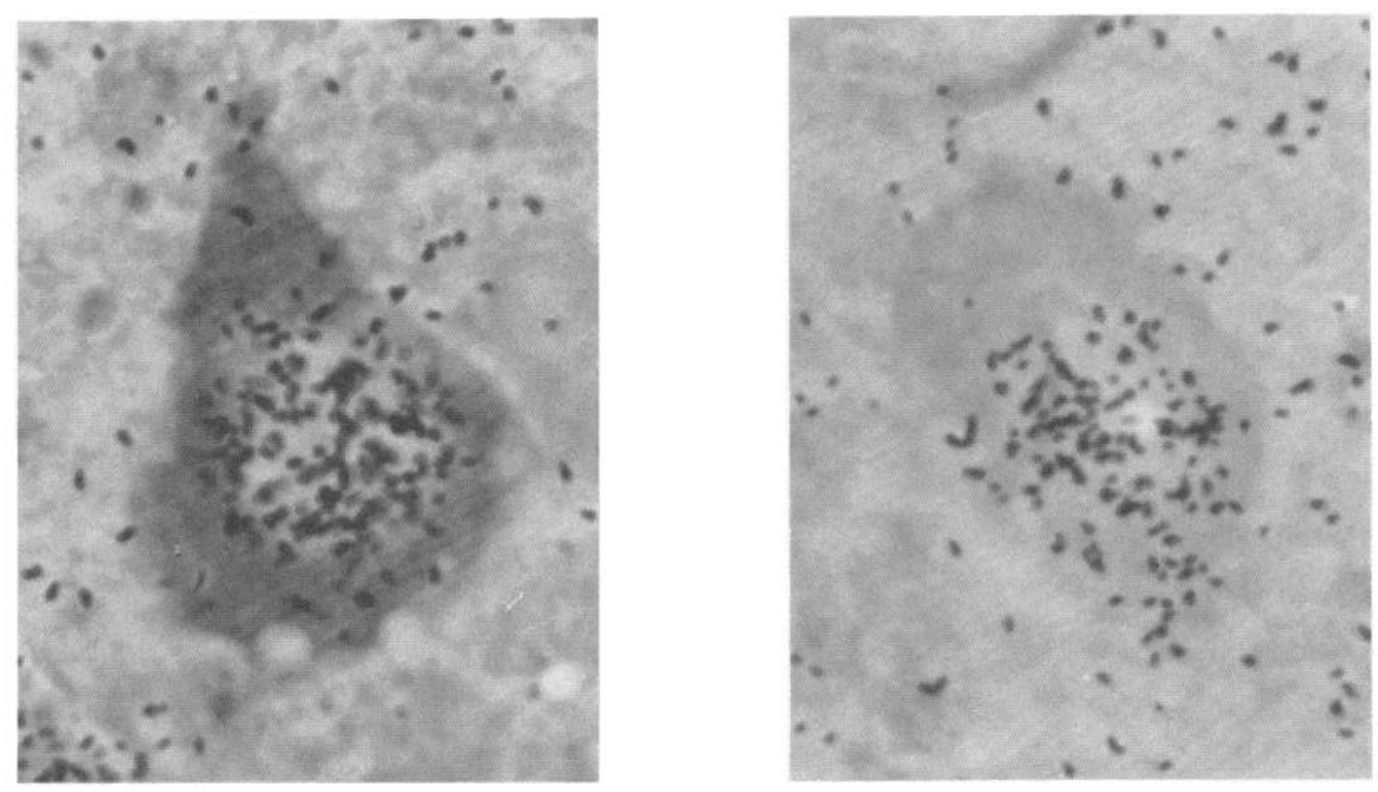

Figure 1. Photomicrographs of magnocellular estrogen-concentrating neurons in the posterior subnucleus of the PVN. The black dots are silver grains which are located preferentially over the nuclei of estrogen-concentrating cells. Stained cytoplasmic regions indicate the immunocytochemical localization of neurophysin. Magnification $\times 2000$. Left, A magnocellular estrogen-concentrating, neurophysin-containing neuron. Right, A magnocellular estrogen-concentrating neuron which does not contain neurophysin. 

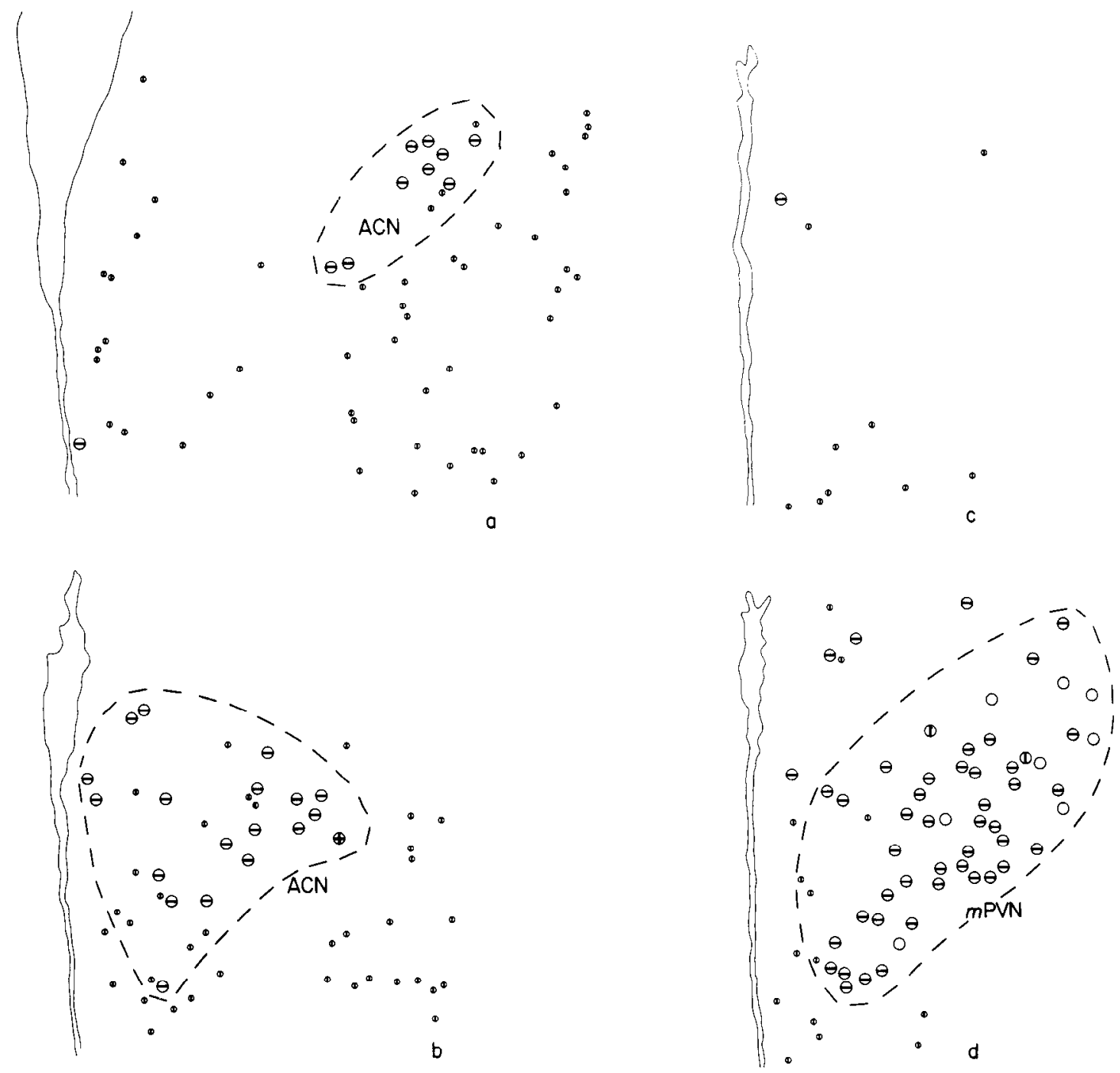

Figure 2. Charts of a typical series of coronal sections of one side of the brain through the ACN and PVN showing estrogenconcentrating and neurophysin-containing cells. All of the magnocellular neurons are shown, but only those parvocellular neurons which concentrated estradiol are indicated. The SON and the fornical nuclei had very few ( $<1$ cell/section) estrogen-concentrating cells. The structure outlined on the left is the third ventricle. Dorsal is toward the top. The bar on the lower right is $100 \mu \mathrm{m}$. $\oplus$, Parvocellular neuron which concentrated estradiol; $O$, magnocellular neuron which neither contained neurophysin nor concel1trated estradiol; $\Phi$, magnocellular neuron which concentrated estradiol; $\Theta$, magnocellular neuron which contained neurophysin; $\oplus$, magnocellular neuron which concentrated estradiol and contained neurophysin. The approximate distances between the charted sections are as follows: $a$ to $b, 90 \mu \mathrm{m} ; b$ to $c, 190 \mu \mathrm{m} ; c$ to $d, 260 \mu \mathrm{m} ; d$ to $e, 114 \mu \mathrm{m} ; e$ to $f, 30 \mu \mathrm{m} ; f$ to $g, 36 \mu \mathrm{m} ; g$ to $h, 80$ $\mu$.

additional $10 \mathrm{~min}$. The tissue then was rinsed in water and counterstained with cresyl violet.

The autoradiograms were scanned systematically with a Zeiss microscope and the location of each cell which either was labeled with the DAB reaction product or met the criterion for autoradiographic labeling was noted. An autoradiographically labeled cell is defined as a cell having an accumulation of reduced silver grains over the nucleus of at least 5 times the background in that region. With the aid of a camera lucida, detailed anatomical charts were made showing the location of all of the magnocellular neurons and only the autoradiographically labeled parvocellular cells. Sections to be analyzed were selected far enough apart to avoid counting the same nucleus twice. Approximately 500 cells were counted in each animal.

\section{Results}

Using a combination of immunocytochemical and steroid autoradiographic techniques, we have demonstrated the existence of neurons in the paraventricular nucleus of the Brattleboro rat which concentrate estradiol in their nuclei and contain neurophysin in their cytoplasm (Fig. 1). Estradiol-labeled magnocellular nuclei also were observed in cells which were not stained with the $\mathrm{DAB}$ reaction product. In addition, many magnocellular neurons, both with and without neurophysin in their cytoplasm, did not concentrate estradiol in their nuclei.

The overall distribution of estrogen-concentrating magnocellular neurons in the Brattleboro rat was similar to that previously observed in the parent strain LongEvans rat (Rhodes et al., 1981a). The distribution of neurophysin-containing magnocellular neurons was sim- 


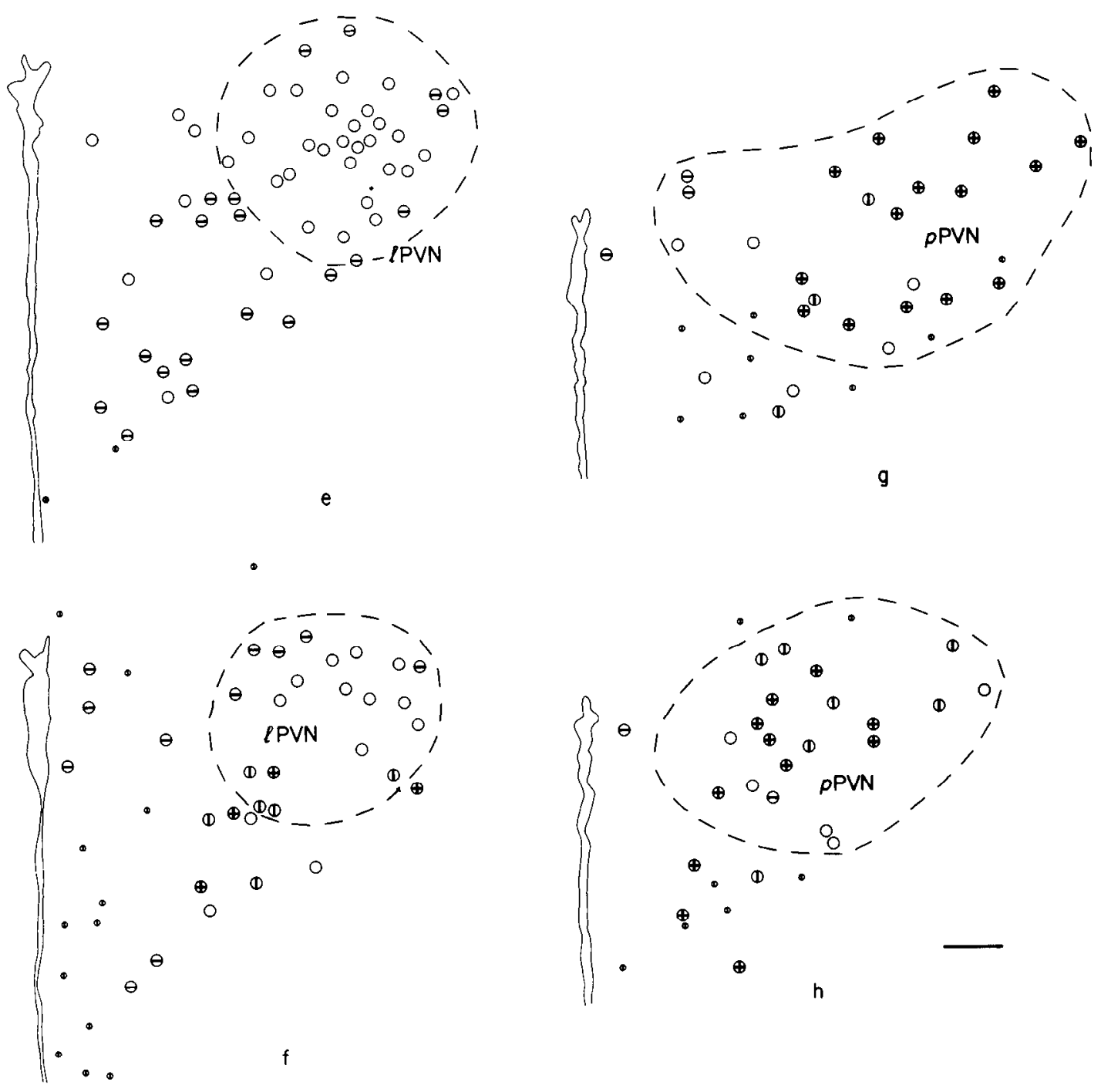

Figure 2. Continued

ilar to that previously observed in the Brattleboro rat (Rhodes et al., 1981b). The immunocytochemical staining was somewhat more intense than that observed in comparably treated Long-Evans tissue.

Magnocellular neurons concentrating estradiol were found almost exclusively in the paraventricular nucleus (PVN). Within that nucleus, they were located in a region medial and ventral to the lateral subnucleus (IPVN) and within the posterior subnucleus (pPVN). (See Rhodes et al., $1981 \mathrm{~b}$, for the nomenclature of the subnuclear divisions of the PVN.) The majority of both the neurophysincontaining, estradiol-concentrating neurons and the neurophysin-lacking, estradiol-concentrating neurons were found in these subdivisions. Neurophysin-containing and neurophysin-lacking neurons were not segregated from each other within these regions. The medial subnucleus of the PVN (mPVN) and the anterior commissural nucleus (ACN) were composed largely of neurophysin-containing magnocellular neurons which did not concentrate estradiol. The IPVN was composed predominantly of cells which did not concentrate estradiol, with neurophysin-containing cells forming a rim around a core of neurophysin-negative magnocellular neurons. Figure 2 illus- trates the distribution of all types of these neurons in the ACN and PVN of a typical rat. Very few (an average of less than $1 /$ section) estradiol-labeled cells were found in the fornical nucleus or supraoptic nucleus (SON).

Table I summarizes the distribution of neurophysincontaining and estradiol-concentrating neurons in the ACN and PVN. Two-thirds of the magnocellular neurons in the pPVN concentrated estradiol in their nuclei. About half of those estradiol-concentrating cells were labeled with the DAB reaction product which marked the immunocytochemical localization of neurophysin. In the region medial and ventral to the IPVN, less than onethird of the magnocellular neurons concentrated estradiol. Of those, $39 \%$ were labeled with DAB. Within the ACN, mPVN, IPVN, and SON, less than $3 \%$ of the magnocellular neurons concentrated estradiol.

\section{Discussion}

Using a technique which combined steroid autoradiography and immunocytochemistry on the same tissue, we demonstrated the existence of magnocellular neurons which concentrate estradiol $(\mathrm{E}+)$ and contain neurophy$\sin (\mathrm{Np}+)$ as well as magnocellular neurons which con- 
TABLE I

Distribution of estrogen binding and neurophysin production in magnocellular neurons in six Brattleboro rats

In that strain, the magnocellular neurons with neurophysin are oxytocin producing, while the magnocellular neurons without neurophysin are the cells which produce vasopressin in the parent Long-Evans. Very few ( $<1$ cell/section) estrogen-concentraing cells were found in the fornical nuclei or SON.

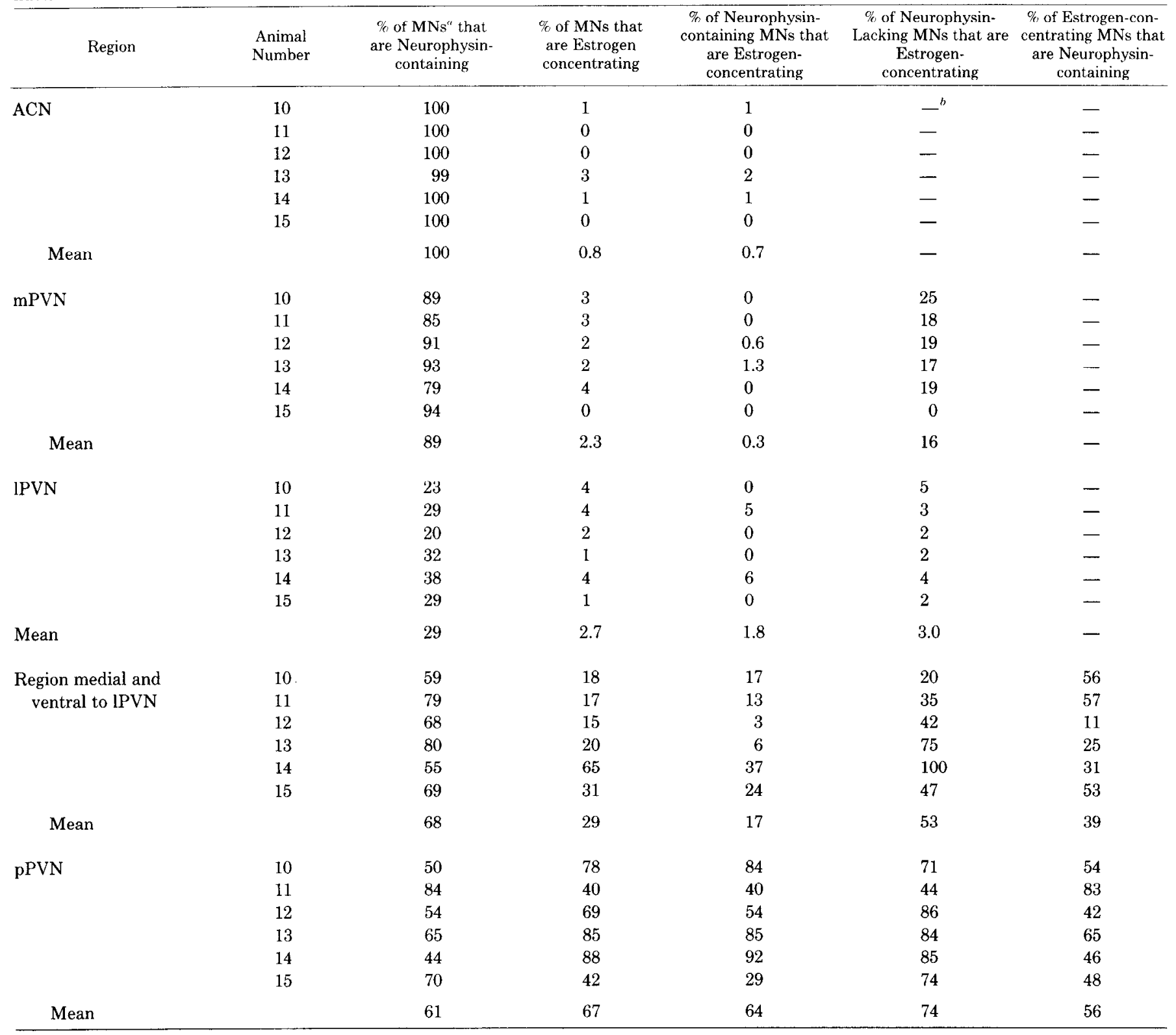

${ }^{a} \mathrm{MNs}$, magnocellular neurons.

D, denominator was less than 9 cells counted.

centrate estradiol but do not contain neurophysin in the Brattleboro strain rat. This animal is congenitally unable to produce vasopressin or the vasopressin-associated neurophysin but does have in its hypothalamus the magnocellular neurons which, in parent strain Long-Evans rats, produce vasopressin (Rhodes et al., 1981b). In the Brattleboro rat, all of the $\mathrm{Np}+$ neurons are oxytocinproducing cells, while the magnocellular NP- neurons are the cells which, in the parent strain, produce vasopressin. These results suggest that, in the Long-Evans rat, there are both oxytocin- and vasopressin-containing cells in the subpopulation of magnacellular neurons which concentrate estradiol.

The immunocytochemically stained neurons observed in the Brattleboro tissue examined in this study were stained more intensely and recognized more easily than similar cells observed in the study of the Long-Evans rat (Rhodes et al., 1981a). Whether this was due to subtle technical differences between the preparations or due to the hypertrophy of the Brattleboro magnocellular neurons associated with increased levels of oxytocin release (Edwards et al., 1982) is not known. 
In the previous study (Rhodes et al., 1981a) of E+, $\mathrm{Np}+$ neurons in the Long-Evans strain rat, estradiolconcentrating magnocellular (presumably neurophysincontaining) neurons which were not stained by the immunocytochemical procedure were observed. The lack of staining was considered to be a technical artifact due to the loss of immunoreactive neurophysin during the autoradiographic procedure. Although a similar loss probably occurred in these experiments, the more robust staining in the Brattleboro tissue indicates that this loss of staining was not as serious a problem in the present study. The substantial number of $\mathrm{Np}-, \mathrm{E}+$ cells observed in sections which also had robust DAB labeling of $\mathrm{Np}+$ cells strongly suggests that at least some of the estradiolconcentrating cells scored as $\mathrm{Np}$ - were in fact without neurophysin in their cytoplasm. Nevertheless, we cannot rule out the possibility that the data reported in Table I include some neurophysin-containing cells which were scored as $\mathrm{Np}-$.

With the criterion of 5 times background used for the autoradiographic results in this study, there is very little chance of false positive autoradiographic results (Morrell and Pfaff, 1981). Assuming that the distribution of reduced silver grains not attributable to specific estradiol binding is a Poisson process-an assumption which will be true if background estradiol is distributed randomly and each tritium particle produces at most one silver grain-then the probability of any region having a background of more than 5 times the average background is given by:

$$
p=\sum_{k=5}^{\infty} \frac{m^{k} e^{\cdots m}}{k !}
$$

where $m$ is the average number of background grains in a nuclear size area of emulsion. With a background level of only one grain per nucleus, there is only 1 chance in 500 of statistical variation producing a false positive. With higher background levels, such an occurrence rapidly becomes much less likely.

A tritium $\beta$ particle is expected to travel only about 2 $\mu \mathrm{m}$ in tissue (Rogers, 1973). These experiments were done with sections $6 \mu \mathrm{m}$ thick. False negative autoradiographic results could have been produced if a nucleus which had concentrated estradiol was so far from the photographic emulsion that the $\beta$ particles failed to reach the silver grains. The large size of these nuclei makes it less likely that any given nucleus would be confined to the top $4 \mu \mathrm{m}$ of the section. Nevertheless, a fraction of the estradiol-labeled nuclei can be expected to have been too far from the emulsion to develop any silver grains.

Taken together, these technical considerations could affect the magnitude of the quantitative results presented in Table I. They would not be expected, however, to affect the overall distribution of estrogen-concentrating cells or the conclusion that all four possible combinations of estrogen and neurophysin labeling exist in the Brattleboro rat. The existence of neurophysin (oxytocin)-containing, estrogen-concentrating cells was demonstrated positively by the results of this work (cf., Fig. 1). The demonstration of the other three classes of cells involve at least one negative result-either the lack of estrogen binding or the lack of neurophysin-and therefore must be approached with more caution. So few estrogen-concentrating cells were observed in the ACN and mPVN, regions which have been shown to contain primarily neurophysin-containing (oxytocin-producing) neurons (Rhodes et al., 1981b), that false negative autoradiographic results due to section thickness could not have accounted for all of the $\mathrm{Np}+, \mathrm{E}-$ cells observed. Similarly, the lack of estrogen binding in the IPVN establishes the existence of $\mathrm{Np}-, \mathrm{E}-$ neurons. The evidence for the existence of $\mathrm{Np}-, \mathrm{E}+$ neurons in the Brattleboro rat is somewhat weaker because those cells are found only in regions which also have neurophysin-containing cells and the degradation of the immunocytochemical results by the prior autoradiographic procedures can make $\mathrm{Np}+$, $\mathrm{E}+$ cells appear to be $\mathrm{Np}-, \mathrm{E}+$. The observation of such cells in sections with excellent neurophysin staining and the presence of an occasional $\mathrm{Np}-, \mathrm{E}+$ cell in the center of the IPVN where neurophysin-containing cells are very rare in the Brattleboro strain make it unlikely that this artifact could account for all of the $\mathrm{Np}-\mathrm{E}+$ cells seen. This is in agreement with a report by Sar and Stumpf (1980) on vasopressin cells (demonstrated with antiserum to vasopressin) in the mouse which concentrate estradiol.

The estrogen-concentrating magnocellular neurons in the Brattleboro rat were found primarily in a region immediately ventral and medial to the IPVN and in the posterior subnucleus of the PVN. The magnocellular neurons in these areas have been shown to project to the medulla and spinal cord rather than to the pituitary (Armstrong et al., 1980; Swanson and Kuypers, 1980). The anatomical distribution of estradiol-concentrating magnocellular neurons reported here strongly suggests, but does not prove, that many of the magnocellular neurons which send their axons into the brainstem are estrogen responsive.

The peptide content of the neurons in the PVN which project to the medulla has been examined by a technique combining a HRP retrograde tracer and oxytocin and vasopressin immunocytology (Sofroniew and Schrell, 1981). Oxytocin-containing neurons and vasopressin-containing neurons, which showed retrograde transport of HRP from the medulla, both were found in the posterior PVN and ventral and medial to the lateral PVN. Although the physiological function of these cells remains unclear, it is evident that the posterior subnucleus of the PVN contains a complex mixture of oxytocin- and vasopressin-producing cells, some of which concentrate estrogen and many of which send their axons to such diverse targets as the nucleus of the solitary tract and the intermediolateral column of the spinal cord.

The remainder of the hypothalamic magnocellular neurons (less than $3 \%$ of which concentrate estradiol) send their axons to the posterior pituitary, where they release oxytocin and vasopressin in response to stimuli associated with changes in salt and water balance, with nursing, or with parturition. The functional significance of estrogen-induced oxytocin and vasopressin release (Yamaguchi et al., 1979; Skowsky et al., 1979) is unknown, but those peptides may be involved in the changes in water balance associated with menstruation. A comparison of the anatomical distribution of estradiol-concentrating magnocellular neurons reported here and the 
distribution of magnocellular neurons which can be labeled by HRP injections into the pituitary (Sherlock et al., 1975; Armstrong et al., 1980; Swanson and Kuypers, 1980) does not support the suggestion that the estrogeninduced release of oxytocin or vasopressin from the posterior pituitary is mediated by estrogen binding by magnocellular neurons.

\section{References}

Armstrong, W. E., S. Warach, G. I. Hatton, and T. H. McNeill (1980) Subnuclei in the rat hypothalamic paraventricular nucleus: A cytoarchitectural, horseradish peroxidase, and immunocytochemical analysis. Neuroscience 5: 1931-1958.

Burford, G. D., C. W. Jones, and B. T. Pickering (1971) Tentative identification of a vasopressin-neurophysin and an oxytocin-neurophysin in the rat. Biochem. J. 124: 809-813.

Crowley, W. R., T. L. O'Donohue, J. M. George, and D. M. Jacobowitz (1978) Changes in pituitary oxytocin and vasopressin during the estrous cycle and after ovarian hormones: Fvidence for mediation by norepinephrine. Life Sci. 23: 25792586.

Edwards, B. R., F. T. LaRochelle, Jr., and M. Gellai (1982) Concentration of urine by dehydrated Brattleboro homozygotes: Is there a role for oxytocin? Ann. N. Y. Acad. Sci., in press.

Keefer, D. A., W. E. Stumpf, and P. Perusz (1976) Quantitative autoradiographic assessment of $\left[{ }^{3} \mathrm{H}\right]$-estradiol uptake in imnunocy tochemically characterized pituitary cells. Cell Tissue Res. 166: 25-35.

Morrell, J. I., and D. W. Pfaff (1981) Autoradiographic technique for steroid hormone localization: Application to the vertebrate brain. In Neuroendocrinology of Reproduction, N. T. Adler, ed., pp. 519-531, Plenum Publishing Corp., New York.

Pfaff, D., and M. Keiner (1973) Atlas of estradiol-concentrating cells in the central nervous system of the female rat. J. Comp. Neurol. 151: 121-158.

Rhodes, C. H., J. I. Morrell, and D. W. Pfaff (1981a) Distribution of estrogen-concentrating, neurophysin-containing magnocellular neurons in the rat hypothalamus as demonstrated by a technique combining steroid autoradiography and im- munohistology in the same tissue. Neuroendocrinology 33: $18-23$.

Rhodes, C. H., J. I. Morrell, and D. W. Pfaff (1981b) Immunohistochemical analysis of magnocellular elements in rat hypothalamus: Distribution and numbers of cells containing neurophysin, oxytocin, and vasopressin. J. Comp. Neurol. 198: 45-64.

Rhodes, C. H., J. I. Morrell, and D. W. Pfaff (1981c) Changes in oxytocin content in the magnocellular neurons of the rat hypothalamus following water deprivation or estrogen treatment: Quantitative immunohistological studies. Cell Tissue Res. 216: 47-55.

Rogers, A. W. (1973) Techniques of Autoradiography, Elsevier/ North-Holland, New York.

Sar, M., and W. E. Stumpf (1980) Simultaneous localization of $\left[{ }^{3} \mathrm{H}\right]$ estradiol and neurophysin $\mathrm{I}$ or arginine vasopressin in hypothalamic neurons demonstrated by a combined technique of dry-mount autoradiography and immunohistochemistry. Neurosci. Lett. 17: 179-184.

Sherlock, D. A., P. M. Field, and G. Raisman (1975) Retrograde transport of horseradish peroxidase in the magnocellular neurosecretory system of the rat. Brain Res. 88: 403-414.

Skowsky, W. R., L. Swan, and P. Smith (1979) Effects of sex steroid hormones on arginine vasopressin in intact and castrated male and female rats. Endocrinology 104: 105-108.

Sofroniew, M. V., and U. Schrell (1981) Evidence for a direct projection from oxytocin and vasopressin neurons in the hypothalamic paraventricular nucleus to the medulla oblongata: Immunohistochemical visualization of both the horseradish peroxidase transported and the peptide produced by the same neurons. Neurosci. Lett. 22: 211-217.

Sternberger, L. A. (1974) Immunocytochemistry, Prentice-Hall, Englewood Cliffs, N J.

Swanson, L. W., and H. G. J. M. Kuypers (1980) The paraventricular nucleus of the hypothalamus: Cytoarchitectonic subdivisions and organization of projections to the pituitary, dorsal vagal complex, and spinal cord as demonstrated by retrograde fluorescence double-labeling methods. J. Comp. Neurol. 194: 555-570.

Yamaguchi, K., T. Akaishi, and H. Negoro (1979) Effect of estrogen treatment on plasma oxytocin and vasopressin in ovariectomized rats. Endocrinol. Jpn. 26: 197-205. 